\title{
Daria Jankowiak
}

Daria Jankowiak - magister socjologii oraz dziennikarstwa i komunikacji społecznej, doktorantka w Katedrze Kulturoznawstwa na Wydziale Filologicznym UMK. Zainteresowania badawcze: fikcje fanowskie, fantastyka, socjologia literatury. 


\section{Fanfikcja jako przykład instrumentalizacji literatury, czyli niespodziewane (z)użycie tekstów literackich}

\section{Preliminaria}

Teraźniejszość stanowi dla literatury okres liberalizacji w zakresie jej tworzenia, publikowania i rozpowszechniania. Ograniczenia z przeszłości (od cenzury zaczynając, poprzez drukarskie limity, a na kosztach dostępności do książki kończąc) tracą obecnie rację bytu. Wolność słowa wyraża się poprzez twórczą samowolę i samodecyzyjność jednostek w udostępnianiu treści poprzez internetowe platformy. Takie realia konsekwentnie pogłębiają aktywizowanie się czytelnika, a twórcę literackiego skłaniają do modyfikacji poglądów na temat tworzenia literatury i jej zastosowań.

Tematem artykułu jest fan fiction (inaczej: fanfikcja, fikcja fanowska, fanfik, fik) jako przykład instrumentalizacji literatury. Fan fiction, czyli piśmiennictwo fanów (m.in. literatury), rozpatruję pod względem rozpowszechniania się pozaestetycznych funkcji literatury. Fanfikcję uznaję za przykład nowych zastosowań tekstów literackich, odnoszących się zarówno do jej czytania, jak i pisania ${ }^{1}$.

1 Stąd też twórczość fanfikcyjną określam mianem „piśmiennictwa”, nie przyznając jej tym samym miana „literatury" jako takiej. To rozróżnienie, wprowadzane przeze mnie celowo, nie jest wynikiem jakichkolwiek rozstrzygnięć w ujmowaniu literatury i jej granic (nie jest to bowiem tematem artykułu), ale stanowi przejaw pragmatyzmu i dążenia do klarowności wywodu wokół fan fiction.

Dylemat uznania literackości tekstów, z którym przychodzi się mierzyć, współcześnie doskonale przedstawiają słowa Grzegorza Godlewskiego: „Od ponad wieku w przestrzeni komunikacyjnej Zachodu, a czasem i świata, pojawiają się kolejne media - elektroniczne i cyfrowe - które nie tylko stanowią coraz istotniejszy kontekst dla przekazów literackich, ale również same stwarzają nowe ich postaci. Literatura porzuca okładki książek i wkracza w nowe obiegi i systemy komunikacji, żywiąc się innymi niż «litera» substancjami znakowymi, poszukując nowych form i funkcji, w nowy sposób definiując status autora i odbiorcyi ich wzajemne relacje. Gdy w wyniku tych procesów tracą moc kolejne, stosowane dotychczas kryteria «literackości», w końcu musi pojawić się wątpliwość: czy to jeszcze literatura? Podobnie jak wytyczanie miejsca dla form tradycyjnych w przestrzeni współczesnej refleksji towarzyszy, explicite bądź implicite, pytanie: czy to już literatura?" (za: G. Godlewski, Słowo - pismo - sztuka słowa. Perspektywy antropologiczne, Warszawa 2008, s. 268). 
Problematyka funkcji pozaestetycznych literatury nie jest zagadnieniem sprecyzowanym - trudno jednoznacznie określić oczekiwania wobec tekstów literackich stawiane przez czytelników, autorów, wydawców czy krytyków literackich. Z kolei właśnie te oczekiwania bezpośrednio przekładają się na przypisywane literaturze funkcje użytkowe i potencjalne możliwości zastosowań.

Obecnie można zaobserwować szczególny nacisk kładziony na funkcjonalność literatury, który pojawia się po stronie odbiorców. Tak rozumiana funkcjonalność nie jest już potencjalną społeczną użytecznością (odgórnie, czyli odautorsko zaplanowaną lub przynajmniej przewidywaną), ale społecznym wymogiem (w różnoraki sposób ujmowanym), który odbiorcy stawiają i (co charakterystyczne) równocześnie sami zabierają się za jego spełnienie. Niezależnie, czy dzieje się to za zgodą autora tekstu, czy bez jego zgody lub może przy całkowitej jego niewiedzy. Niezależnie, czy tekst literacki nabywa przez to dodatkowych walorów (również estetycznych!), czy zostaje ich zupełnie pozbawiony. Niezależnie od początkowych zamierzeń twórców literackich i od początkowego przeznaczenia tekstu literackiego.

Niezależnie od (a właściwie: pomimo) pierwotnej celowości literatury, dzięki odbiorcom (a może: przez odbiorców) jest ona instrumentalizowana i użytkowana na wiele sposobów, które często przerastają wizje autora, jednocześnie niwelując (możliwe, że nawet na zawsze) nadane przez niego znaczenie spisanej historii.

\section{Fanfikcja i jej miłośnicy}

Metakultura to kultura, która mówi o innej kulturze i która nieustannie wytwarza warunki ku temu, aby komentować i projektować kolejne poziomy własnej ekspansji. Dzisiejszy świat jest właśnie w tym sensie metakulturowy, że dzięki masowym mediacjom jakikolwiek wytwór kulturowy, który się pojawia, nigdy nie jest tworzony jako odrębny element, ale już w punkcie wyjścia stanowi część symultanicznej totalności. [... ] Jedną z konsekwencji owego oparcia na doświadczeniu zapośredniczonym $[\ldots]$ jest to, że zmętnieniu uległy kryteria odbioru literackiego ${ }^{2}$.

Rzeczywistość literacka została zdominowana przez dwa problematyczne zjawiska, które (jak okaże się w dalszej części artykułu) odzwierciedlają się w powstawaniu i popularności fikcji fanowskich. Pierwszym zjawiskiem jest permanentny brak poczucia „nowatorstwa” czytanej literatury, który obrazowo określa stwierdzenie: „To wszystko już gdzieś było". Kwintesencją takiego stanu rzeczy jest powtarzalność i schematyczność, wznoszona na literackich fundamentach odniesień do wcześniej powstałych i upublicznionych wytworów kultury. Drugim - owo zmętnienie kryteriów odbioru literackiego; zmętnienie dokonujące się na skutek przemian społecznych, związanych przede wszystkim z egzystowaniem $\mathrm{w}$ dobie nowych mediów.

Taki kontekst sytuacyjny okazuje się sprzyjający dla tekstów fanfikcyjnych. Termin „fan fiction”, w przekładzie na język polski określany przede wszystkim jako fikcja fanowska, fanfikcja ${ }^{3}$, fanfik (fanfic) czy fik (fic), odnosi się do literackiej amatorskiej twórczości

\footnotetext{
2 W. J. Burszta, W. Kuligowski, Sequel. Dalsze przygody kultury w globalnym świecie, Warszawa 2005, s. 17-18.

${ }^{3}$ M. Kamińska, Niecne memy. Dwanaście wykładów o kulturze Internetu, Poznań 2011.
} 
fanowskiej. Teksty fanfikcyjne powstają, opierając się na istniejących już dziełach, niezależnie od tego, czy są nimi książki, filmy, seriale, komiksy czy inne wytwory kulturowe ${ }^{4}$. Właśnie ten związek z dziełem oryginalnym (kanonicznym) postrzegany jest jako podstawa fikcji fanowskich ${ }^{5}$. Ważne jest to, że fan fiction odróżnia się od fan artu, czyli wizualnej amatorskiej twórczości fanowskiej.

Fikcje fanowskie uznaje się za gatunek ${ }^{6}$ piśmiennictwa popularnego. Stanowią one zwykle efekt tworzenia $\mathrm{w}$ internetowej społeczności ${ }^{7}$. Stąd też są postrzegane jako jedne $\mathrm{z}$ tak zwanych new literacies ${ }^{8}$, czyli form piśmienności możliwych dzięki rozwojowi technologicznemu i powstaniu Internetu'. Początki fan fiction odnotowuje się jednak nie na platformach wirtualnych, ale w gazetkach fanowskich, to jest fanzinach ${ }^{10}$. Za pierwsze fanfikcje uchodzą teksty, które ukazały się właśnie w formie papierowej w zinach - na kanwie „Star Treka” Ich publikację datuje się najczęściej na koniec lat $60 .{ }^{12}$ Warto nadmienić, że geneza piśmiennictwa fanfikcyjnego sięga aż momentu, od którego można mówić o powstawaniu utworów literackich cieszących się popularnością ${ }^{13}$. Popularność ta oczywiście musiała mieć bezpośrednie przełożenie na zaangażowanie czytelnicze, by skłonić odbiorców danego dzieła literackiego do własnych działań postliterackich w postaci piśmiennictwa na jego kanwie.

Biorąc pod uwagę rozkwit literackiej amatorskiej twórczości fanowskiej w sieci, niezbędne jest określenie cech charakterystycznych fan fiction. Linda Green ${ }^{14}$ podaje jako elementy wyróżniające tego typu twórczość: ustanowione (established) postacie, światy i historie (czyli zaczerpnięcie fabuly z dzieła oryginalnego); brak profitów finansowych uzyskiwanych z piśmiennictwa fanfikcyjnego; amatorskiego autora oraz założenie, że fanfikcja jest utworem zależnym (derivative work). Wskazane cechy odnoszą się bezpośrednio do rozpatrywania fikcji fanowskich jako tekstów drugorzędnych, niemających prawa i możliwości istnieć bez swojego fundamentu, którym jest dzieło oryginalne, a także bez jego zaangażowanego czytelnika, nierzadko stającego się autorem/twórcą fanfikcyjnym.

\footnotetext{
${ }^{4}$ W artykule omawiam problematykę fanfikcji powstałych, opierając się na utworach literackich. Należy jednak mieć na uwadze, że spostrzeżenia i tezy w nim prezentowane można odnieść również do innych dzieł oryginalnych, np. filmów.

${ }^{5}$ L. Gąsowska, Fan fiction, czyli złoto dla zuchwałych. Pomiędzy pragnieniem narracji a realizacją opowieści, [w:] Kody kultury. Interakcja, transformacja, synergia, red. H. Kubicka, O. Taranek, Wrocław 2009, s. 445-454.

${ }^{6}$ Gatunek należy tutaj rozumieć w szerokim ujęciu.

7 L. Green, Entering Potter's World: A Guide for Fanfiction Writers, Lulu.com, 2006, s. 11.

8 N. Luongo, Let's Keep the Fan in Fan Fiction, „Teachers Net Gazette” 2012, [online] http://teachers.net/ gazette/wordpress/nicole-luongo/let\%E2\%80\%99s-keep-the-\%E2\%80\%9Cfan\%E2\%80\%9D-in-fan-fiction/ (data dostępu: 19 IV 2012).

9 Termin „new literacies” odnosi się czasem również do twórczości audio i video, których powstawanie również umożliwił rozwój technologiczny.

10 Precyzując, fanzin „to gazetka przygotowana i wydawana poza oficjalnym obiegiem, zgodnie z założeniami DIY (Dolt Yourself - ang. zrób to sam), najczęściej przez jedną osobę (pełniącą wszystkie redakcyjne funkcje: autora tekstów, redaktora, grafika, korektora, dystrybutora itp.). Ważnym założeniem jest również chęć pozostania poza oficjalnymi kanałami dystrybucji kultury: jest to świadomy wybór autorów" (za: B. Głowacki, Prasa trzeciego obiegu w okresie przełomu, „Kultura - Media - Teologia” 2010, nr 3, s. 36).

${ }^{11}$ R. Mazar, Slash fiction/Fanfiction, [w:] International Handbook of Virtual Learning Environments, red. J. Weiss, J. Nolan, J. Hunsinger, P. Trifonas, Dordrecht 2006, s. 1141-1150.

12 Ibidem; I. Arnold, Wenn Spock und Kirk sich plötzlich küssen, "Berliner Zeitung” 2010, [online] http:// www.berliner-zeitung.de/archiv/serien-fans-schreiben-im-internet-ihren-stars-eigene-geschichten-auf-denleib---mit-recht-skurrilen-ergebnissen-wenn-spock-und-kirk-sich-ploetzlich-kuessen,10810590,9838054.html (data dostępu: 14 IV 2012); K. Czajka Fikcja po fikcji, „Polityka” 2011, nr 28, s. 64-66.

13 B. Kulesza, Zagadnienie autorstwa w utworach fan fiction. Fandom jako kolektyw twórczy, [w:] Remiks. Teorie i praktyki, red. M. Gulik, K. Kaucz, L. Onak, Kraków 2011, s. 63.

14 L. Green, op. cit., s. 11-14.
} 


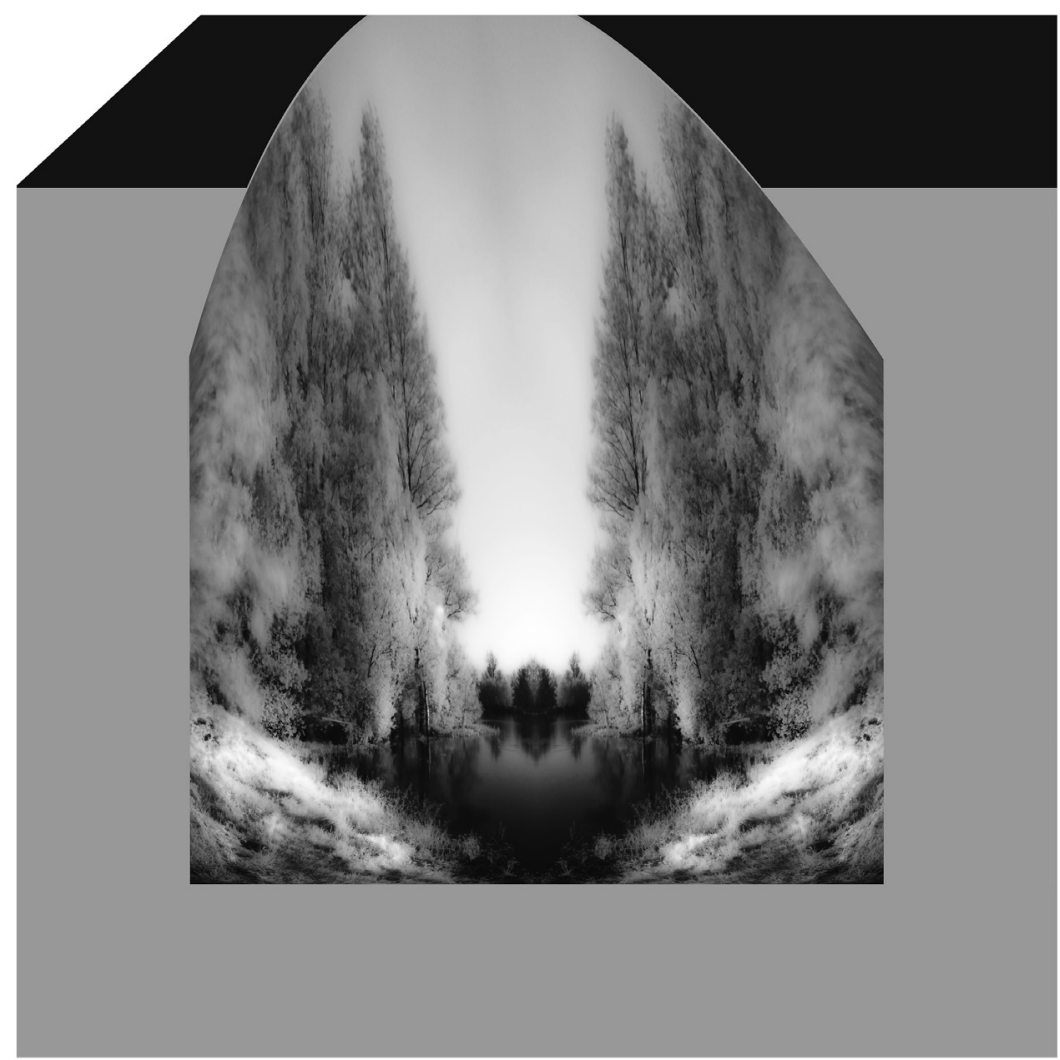

Nie mniej istotne od sformułowania cech wspólnych fikcji fanowskich jest określenie cech je różnicujących. W ramach tego typu amatorskiej twórczości fanowskiej wyodrębniło się wiele podgatunków, m.in. ze względu na długość utworów fanfikcyjnych i schematyczność ich tematyki. Do najbardziej wyróżniających się podgatunków ze względu na tematykę fanfików ${ }^{15}$ zaliczyć można:

- crossover - historię, w której autor fan fiction umieścił postaci z dwóch różnych źródeł (dzieł oryginalnych);

- slash - historię opierającą się na homoerotycznej lub homoseksualnej relacji między dwoma postaciami, której nie było lub nie została przedstawiona w dziele oryginalnym;

- mpreg - historię, w której mężczyzna zachodzi w ciążę;

- missing scene - historię, która koncentruje się na czymś, co nie zostało przedstawione $\mathrm{w}$ dziele oryginalnym, ale mogłoby się wydarzyć;

- A/U (alternative universe) - historię, w której akcja odbiega od opowieści oryginalnej.

Z kolei w przypadku fikcji fanowskich kategoryzowanych ze względu na długość tekstów wyróżnia się m.in. teksty dłuższe w odcinkach oraz teksty z ograniczeniami co do ilości użytych słów: do pięćdziesięciu słów (dribble), stu (drabble), stu pięćdziesięciu (drabble-and-a-half) i dwustu słów (droubble; double-drabble) ${ }^{16}$.

15 S. Pugh, The Democratic Genre: Fan Fiction in a Literary Context, Glasgow 2005, s. 242-244.

${ }^{16}$ http://tanuki.pl/slownik/tag/fanfiction (data dostępu: 15 IV 2012); M. Małek, Drabble w tłumaczeniu, [w:] Piękno języka specjalistycznego a precyzja języka literackiego, red. K. Fordoński, M. Łukasik, Warszawa 2008, s. 87-94. 
Zważywszy na fakt, że fanfikcje nie są piśmiennictwem wydawanym profesjonalnie, tylko tekstami nieautoryzowanymi i publikowanymi przede wszystkim $\mathrm{w} \operatorname{sieci}^{17}$, $\mathrm{w}$ ramach społeczności wokół nich powstałych wykształciły się mechanizmy i funkcje pełnione przez niektóre osoby zainteresowane fanfikcją w celu oddolnego monitorowania powstających fanfików (jeśli chodzi o ich literacką jakość). Stąd też oprócz czytających i piszących fan fiction są osoby zajmujące się redakcją i korektą tego typu tekstów - beta-readerzy (określani również w skrócie „betami”) ${ }^{18}$.

Zdaniem Leszka Pułki: „kultura mediów jako dominujący nurt kultury popularnej to seria regularnych, zrytualizowanych $[\ldots]$ praktyk komunikacyjno-estetycznych, z trudem dających się racjonalizować (zwłaszcza jako fenomeny odbioru), lecz bez trudu nadawanych"19. Piśmiennictwo fanfikcyjne, mając swój początek m.in. w literaturze, doprowadza do sytuacji, w której poszczególne funkcje literatury otrzymują swoiste przedłużenie w kolejnych tekstach i działaniach czytelników na tekście. Fan fiction, będąc formą pozaautorską, jest użyciem literaturę zmieniającą. Zmiana ta nie zawsze jest uważana za progres, ale z pewnością należy ją uznać za pewien fenomen odbioru, który niejako zmusza pisarza (autora dzieła oryginalnego) do zastanowienia się nad miejscem przysługującym obecnie czytelnikowi.

Jak pisarz nadaje kształt odbiorcy, dla którego pisze? Byłoby głupotą sądzić, że piszący, kierując swą wypowiedź do tzw. powszechnego odbiorcy, usiłuje sobie wyobrazić poszczególnych czytelników. [...] Nie ma potrzeby, by pisarz w taki sposób odczuwał swego „odbiorcę”. Choć może się oczywiście zdarzyć, że wyobrazi sobie, iż zwraca się do tego, czy innego konkretnego człowieka. Z pewnością jednak nie zwraca się do wszystkich swoich czytelników, i to uwzględniając ich konkretne uwarunkowania. W praktyce wszakże, pod presją oczekiwań redaktorów i wydawnictwa, musi brać po uwagę rzeczywisty stan społeczny, ekonomiczny i psychologiczny ewentualnych czytelników. Musi napisać książkę, którą żywe osoby kupią i przeczytają. Mówię tu - czy piszę - o „odbiorcy”, który rozpala wyobraźnię pisarza ${ }^{20}$.

W realiach piśmiennictwa fanfikcyjnego pisarz staje przed koniecznością przewartościowania swojej postawy autora. Czy istnieje jakakolwiek szansa na to, by wyobraźnię pisarza rozpalał właśnie odbiorca zaangażowany w tworzenie i czytelnictwo fan fiction? Może być on (tenże odbiorca) przecież jednym z najwierniejszych czytelników, znającym świetnie opowiadaną przez autora na kartach książki historię i będącym do niej w dużym stopniu przywiązany. Ten sam odbiorca nagina dotychczasowe zasady określające jego relację z pisarzem, przypisując sobie praktycznie te same (a może nawet większe) prawa do tekstu literackiego co jego autor. Czy pisarz, myśląc o odbiorcy, jest w stanie zdobyć się na rzeczywisty obraz czytelnika fanfikcyjnego, który przenicuje jego twórczość z redakcyjną wręcz skrupulatnością, a potem prawdopodobnie - podda ją totalnej metamorfozie, czy raczej woli pozostać w nieświadomo-

17 Choć taki stan rzeczy uznaje się za jedno z głównych założeń piśmiennictwa fanfikcyjnego, zważywszy na jego rosnącą w ostatniej dekadzie popularność można na chwilę obecną spotkać się z przykładami publikowanych profesjonalnie fanfikcji, nazywanych profikami.

${ }_{18}$ Beta-readerzy czytają i przekazują swoje uwagi do tekstów fanfikcyjnych ich autorom jeszcze przed opublikowaniem w sieci. Uwaga ta jest o tyle godna odnotowania, że w ramach społeczności fanfikcyjnych powszechnym zjawiskiem jest szczegółowe analizowanie i opiniowanie ukazujących się fanfików przez ich czytelników.

${ }^{19}$ L. Pułka, Kultura mediów i jej spektakle na tle przemian komunikacji społecznej i literatury popularnej, Wrocław 2004, s. 8.

20 W. J. Ong, Osoba -świadomość - komunikacja, Warszawa 2008, s. 58-59. 
ści, niewiedzy o współczesnym czytelniku? Pisarz niekoniecznie jest już gotowy na dokonujące się na jego oczach (a raczej na jego autorskim tekście) uelastycznianie literatury wynikające z czytelniczych potrzeb. Potrzeb, które - z punktu widzenia nieprzygotowanego na obecne zmiany w relacjach z czytelnikiem pisarza - mogą wydawać się bezpodstawnymi roszczeniami, burzącymi dotychczasowy „tad druku”. Do chwili obecnej pisarze i czytelnicy funkcjonują zazwyczaj w dysharmonii wzajemnej wiedzy o sobie, a także przyznawanego przez nich tekstowi literackiemu przeznaczenia ${ }^{21}$.

Analizując literaturę z punktu widzenia jej zastosowań w fan fiction, warto przyjrzeć się grupom zainteresowanym tego typu piśmiennictwem. Rozwój zjawiska tworzenia fikcji fanowskiej rozegrał się (i nadal rozgrywa) w warunkach sieci, precyzyjniej - Web 2.0. Osoby zainteresowane fanfikcją są przede wszystkim użytkownikami portali i forów internetowych poświęconych i zajmujących się tym piśmiennictwem. Oczywiście sieć stanowi raczej platformę potencjalnych nowych możliwości czytelniczej aktywności, niż jest czynnikiem decydującym o wykrystalizowaniu się zapotrzebowania odbiorców na taką formę instrumentalnego użytkowania dzieł oryginalnych - ono istniało również wcześniej, nie miało jednak tak sprzyjających warunków do rozwoju jak współcześnie.

W takim kontekście fanfikcyjny odbiorca literacki ma przede wszystkim szanse realizować swoje czytelnicze aspiracje w sieci. Jest to o tyle istotne, o ile zdajemy sobie sprawę $\mathrm{z}$ cech osób będących użytkownikami Internetu. Potencjalny odbiorca fanfikcyjny (w najbardziej podstawowym i ogólnym ujęciu) to przeciętny użytkownik sieci, a nawet (przyjmując za fakt zaangażowanie w sieciową rzeczywistość) przedstawiciel tzw. generacji sieci, czyli (generalizując) osób w młodym wieku, wyrastających w trakcie intensyfikowanego wykorzystywania Internetu, nastawionych na aktywność i decyzyjność w podejmowanych działaniach w jego ramach.

Kolejną cechą charakteryzującą fanfikcyjnego odbiorcę jest jego (nader częsta) fanowska przynależność (sformalizowana lub nie) do grupy zainteresowanych danym dziełem oryginalnym, co wiąże się z zaangażowaniem w dzieło, objawiającym się między innymi jego doskonałą lub przynajmniej bardzo dobrą znajomością, otwarciem na jego potencjalną kontynuację, ekranizację bądź inną formę jej zwielokrotnienia w kulturze.

Fan fiction pisane i czytane jest przeważnie przez kobiety ${ }^{22}$. Błędne jednak byłoby branie tego typu tekstów za przykład piśmiennictwa kobiecego - ze względu na różnorodność fabularną samych tekstów, jak i dzieł oryginalnych, na których podstawie powstają. Zważywszy jednak na to, że społeczności fanfikcyjne w dużym stopniu funkcjonują w szerszych zbiorowościach fanowskich (związanych często $\mathrm{z}$ fantastyką), można wysunąć przypuszczenie, że jest to przejaw powstania pewnego rodzaju niszy dla żeńskiej części tej zbiorowości²3.

\footnotetext{
${ }^{21}$ Nie wypracowano do tej pory warunków wzajemnego współegzystowania twórców dzieł oryginalnych (pisarzy) i twórców fanfikcyjnych (odbiorców literatury). Na przeszkodzie temu stoją niejasności związane z prawem autorskim i zachwianiem jego znaczenia w dobie Web 2.0, a także całkowite zrównanie pozycji twórców i odbiorców, na co nie zawsze pierwsi z nich wyrażają zgodę. W praktyce środowiska fanfikcyjne funkcjonują często bez wiedzy i zgody autorów dzieł literackich, które były impulsem decydującym o ich utworzeniu. Nie znaczy to, że dla miłośników fanfikcyjnych nie liczy się zdanie autora ich ulubionego dzieła. Wykazują oni zainteresowanie ich opinią, co jednak nie wpływa na ich „otwarty” sposób myślenia o tekście. Pisarz zostaje niejednokrotnie postawiony w sytuacji patowej - przeciwstawienie się czytelniczym potrzebom fanfikcyjnym może być jednoznaczne z utratą czytelnika lub jego poważania, a wyrażenie aprobaty względem fanfikcji wymaga natomiast całkowitej i drastycznej zmiany podejścia do swojego autorskiego tekstu literackiego.

22 R. Mazar, op. cit.

${ }^{23}$ Formalnie jednak nie istnieją w fandomie żadne kryteria ograniczające jego członków co do poszczególnych aktywności fanowskich. Takie więc, a nie inne rozłożenie zainteresowań ze względu na płeć nie jest
} 




Przestrzeń - 013

Najsłuszniejszym sposobem postrzegania odbiorcy fanfikcyjnego jest jednak uznanie, że piszący i czytający fan fiction, tworząc własne społeczności, pomijają, a nawet przeciwstawiają się dzielącym ich barierom czasu, odległości, wieku oraz talentu ${ }^{24}$.

\section{Fanfikcja jako przykład instrumentalizacji literatury}

Internet stał się miejscem sprzyjającym komunikacji literackiej - w wirtualnej przestrzeni następuje przenikanie i wspótistnienie form kultury pisma i druku z formami środowiska elektronicznego ${ }^{25}$. Ta wzajemna współzależność i koegzystencja skłania do zastanowienia się nad faktycznym stanem piśmienniczych zastosowań literatury. Jak zauważył Heiko Idensen:

Teksty online jaśnieją blaskiem nie tyle literackich, co raczej dyskursywnych jakości, takich jak swobodne przerzucanie się między różnymi płaszczyznami, odniesienia do kontekstów, połączenia poprzeczne, szybkość wymiany - inscenizowanie i opracowywanie struktur intertekstu-

wynikiem żadnych obostrzeń, ale osobistych wyborów poszczególnych jednostek do zbiorowości fanowskiej należących.

\footnotetext{
${ }^{24}$ N. Luongo, op. cit.

25 M. Hopfinger, Literatura i media. Po 1989 roku, Warszawa 2010, s. 184.
} 
alnych - projektowanie i rozwijanie idei w warunkach podziału zadań i współpracy. [...] sieć staje się uprzywilejowanym miejscem myślenia... ${ }^{26}$.

Nie oznacza to wcale, że w sieciowym piśmiennictwie nie można odnaleźć pewnych uniwersalnych funkcjonalności literatury - przybierających nowoczesne formy, ale o wyraźnych korzeniach tradycyjnego myślenia o tekście.

W dalszej części artykułu przedstawiam najbardziej charakterystyczne zastosowania literatury w fanfikcji. Odzwierciedlają one użytkowanie społeczne literatury na tyle, na ile jest się skłonnym przyznać do powiązań „tekstów po tekście” (czyli omawianych w artykule fikcji fanowskich) z samym tekstem literackim. Powiązań, które istnieją, choć nie zawsze uznaje się za godne i właściwe je zauważać.

\subsection{Opowieść niech trwa}

To, że fikcyjne historie literackie potrafią porwać tłumy, staje się już truizmem. Społeczną akceptację danej opowieści (a może nawet społeczne jej zapotrzebowanie) mierzy się na wiele sposobów: liczbą sprzedanych egzemplarzy książki, przyznaniem dziełu i jego autorowi nagród literackich, trafieniem na listy bestsellerów czy poprzez tworzenie się wokół danej książki medialno-produkcyjnych dobudowań (takich jak: ekranizacje filmowe i serialowe czy pojawienie się na rynku i wzrost popytu na gadżety nawiązujące do opowieści i jej głównych bohaterów). Historia, która zachwyci odbiorców, zdobywa miejsce w popkulturowej rzeczywistości, z wszelkimi tego stanu konsekwencjami.

Wszystkie wymienione wyżej sposoby rozpropagowywania obecności opowieści i profitów bądź kosztów z tym związanych nie stanowią jednak na dłuższą metę skutecznego sposobu na ciągłe, nieustające trwanie danej opowieści, czyli na to, na czym najbardziej zależy zaangażowanym w jej odbiór miłośnikom. Jakie oczekiwania odbiorców względem opowieści (a przez to także względem jej twórcy, autora) wysuwają się na pierwszy plan?

Przede wszystkim są to: (a) powstanie dalszego ciągu opowieści, bez względu na to, czy jest on przewidywany przez autora tekstu literackiego, czy nie; i (b) maksymalne skrócenie czasu oczekiwania na dalszy ciąg omawianej opowieści. Mówiąc krócej, odbiorca chce więcej i szybciej, niż jest to mu dawane. Ekranizacje danej historii, medialne spekulacje wokół dalszej fabuły dzieła, czy też gromadzenie wokół siebie gadżetów fanowskich z motywem danej historii tylko na chwilę zaspokajają odbiorczy głód opowieści. Głód, który nie jest do końca możliwy do zaspokojenia. Po pewnym czasie autor opublikuje wszystkie tomy danego cyklu książkowego; zostaną one przeniesione na ekrany kinowe i telewizyjne; miłośnik opowieści doczeka się nawet wszelkich możliwych (od entuzjastycznych do nieprzychylnych i krytycznych) recenzji danych przedstawień opowieści (literackich, filmowych itd.). Powstaną również na jej temat prace naukowe, autorzy napiszą lub doczekają się swoich biografii, a dany bohater opowieści czy motyw z niej zaczerpnięty stanie się oczywisty, czytelny i w pełni zrozumiały nawet dla tych, którzy w całości (i w pierwowzorze) nigdy danej historii literackiej nie poznali i nie starali się poznać. Dla samych zaangażowanych w odbiór

26 H. Idensen, Hipertekst - wiedza radosna? O krytyce hipermedialnej techniki i praktyki kulturowej, [w:] Ekrany piśmienniczości. O przyjemnościach tekstu w epoce nowych mediów, red. A. Gwóźdź, Warszawa 2008, s. 294. 
jest to wciąż za mało. Mają oni niejednokrotnie wyśrubowane wymagania względem wybranej opowieści, które nie tyle dotyczą literackiej wartości i jakości opowieści, ale tego, by była ona „niekończącą się opowieścią”.

Antidotum na taki stan rzeczy - konflikt interesów pojawiający się w trakcie tworzenia i multiplikacji opowieści pomiędzy jej autorem i osobami zaangażowanymi w napędzanie rynku wokół danej historii a odbiorcami - okazuje się fan fiction. Fikcje fanowskie pisane i czytane przez miłośników opowieści, czyli osoby najbardziej aktywne w jej odbiorze, z jednej strony pozwalają na dalsze trwanie opowieści po jej faktycznym oficjalnym zakończeniu, z drugiej (w przypadku oczekiwania na kolejny tom cyklu) zapełniają pustkę między jedną częścią a drugą. Takie rozpatrywanie opowieści jest oczywiście wersją dla najbardziej zaangażowanych czytelników, którzy już dokonali (wszelakich?) odkryć w opowieści właściwej, znają doskonale ją i jej potencjalne adaptacje. Niemniej właśnie w fanfikcji odzwierciedlona zostaje swoista pogoń odbiorców za opowieścią, na ich wyraźne życzenie: nieustającą i niemogącą utracić wzbudzanych w czytelnikach emocji.

Odbiorcy nie oczekują już happy endu, chcą zamiast tego, by zakończenie nie następowało. Zadziwiające, że rozwój fikcji fanowskiej (który w uproszczeniu można uznać za skutek pragnienia „trwania opowieści”) obserwuje się w czasach, kiedy czytelnik - odbiorca ma możliwość wyboru spośród niebywałej do tej pory liczby literackich historii. To skupienie się na konkretnej opowieści (będące z drugiej strony pozbawianiem samych siebie innych opowieści) prowadzi do kolejnego problemu użytkowania literatury.

\subsection{Nieskrępowana wolność wyboru}

Choć zdaniem jednego z francuskich socjologów, Pierre’a Bourdieu, odbiór dzieła literackiego, którego podstawą jest poznanie jego zakończenia, czyli doczekanie się rozwiązania opisywanej w tekście intrygi czy też rozwoju relacji między jego bohaterami, stanowi przejaw gustu barbarzyńskiego ${ }^{27}$, niewątpliwie takie pobudki stanowią jedną z głównych motywacji sięgania po literaturę, oczekiwania na kolejne części cyklu, utożsamienia się z bohaterami i (co najważniejsze) potencjalnego ogromnego społecznego zainteresowania daną historią i jej popularnością (przekuwającą się pośrednio na powstawanie na jej kanwie fan fiction).

Fanfiki powstające na podstawie wybranego dzieła, oprócz przedłużania trwania danej opowieści, cechują się odbiorczym oczekiwaniem pewnej decyzyjności względem tekstu. Pozaautorskie decydowanie o tekście literackim, zasadzające się na specyfice fanfikcyjnych odbiorców literackich, preferujących nieskrępowaną wolność wyboru, stosowane jest w różnych celach, przy czym najistotniejszymi i najpowszechniejszymi z nich są: (a) obrona przed znudzeniem się daną opowieścią, jej kanonem ${ }^{28}$; (b) multiplikacja opowieści (w tym, m.in. „drugie życie” dla bohaterów głównych, którzy mają szansę na alternatywny rozwój wydarzeń głównego wątku; „druga szansa” dla bohaterów pobocznych, którzy mają możliwość zaistnieć w opowieści, choć autor dzieła oryginalnego nie przewidział dla nich znaczącego miejsca i roli w utworze); (c) kontrastowanie (czyli na przykład przemiany dobrych

27 A. Matuchniak-Krasuska, Zarys socjologii sztuki Pierre'a Bourdieu, Warszawa 2010.

${ }_{28}$ Kanonem w środowiskach fanfikcyjnych określa się fabułę dzieła oryginalnego - pewną stałą w nastawionych na zmienność i otwartość fikcjach fanowskich. 
bohaterów w złych czy też bohaterów heteroseksualnych w homoseksualnych); (d) zmiany gatunku, a nawet rodzaju literackiego dzieła.

Takie podejście do literatury potwierdza różnorodność odbiorców fanfikcyjnych, będąc jedynym dostępnym wyróżnikiem z masy czytelników literatury, na który właśnie sami czytelnicy (różniący się wiekiem, pozycją społeczno-ekonomiczną, wykształceniem i innymi cechami) mają całkowity wpływ, przejawiający się w preferencjach kształtowania się opowieści poza opowieścią oryginalną, taką samą, a jednak odmienną dla wszystkich jej miłośników.

\subsection{Droga „na skróty”}

Fikcje fanowskie rozumieć można również jako literacką drogę „na skróty” (poza wcześniej opisywanymi motywacjami zainteresowania tego typu piśmiennictwem), wybieraną przez zwolenników fanfikcji świadomie i celowo. Spostrzeżenie to odnosi się zarówno do czytelnictwa, jak i piśmiennictwa fanfikcyjnego.

W przypadku czytelnictwa odbiorcy fanfikcyjni decydują się na czytanie fikcji fanowskiej, a nie innej literatury, ze względu na połączenie w niej elementów: znanego i nowego. To, co znane, pozbawia ich potencjalnego trudu poznawania nowej opowieści, świata przedstawionego i bohaterów fabuły. To, co nowe, okazuje się wprowadzonym przez autora danego fan fiction konceptem (tj. nowym bohaterem, zwrotem akcji w opowieści, itp.). Z kolei piśmiennictwo fanfikcji adekwatnie jest drogą „na skróty”, zdejmującą z piszącego brzemię wymyślania nowego świata i jego bohaterów, przy jednoczesnej realizacji piśmienniczych aspiracji (czyli twórca fanfikcji posiłkuje się w swoim piśmiennictwie tym, co znane).

Omawiane zastosowanie fan fiction sprowadza się do wygody fanfikcyjnych odbiorców literackich i wybiórczości tego, co niesie ze sobą obcowanie z tekstem. Wspomniana wybiórczość objawia się połączeniem znanego i nowego, a nie tylko wyborem jednego z nich (nowego - w wypadku czytania lub pisania autorskiego tekstu; znanego - czyli ponownego skupienia się na lekturze czytanego już kiedyś dzieła literackiego). Nie jest to więc wybiórczość rozumiana dosłownie (jako selektywność), tylko wybór odpowiadających odbiorcy fanfikcyjnemu elementów fikcji literackiej - oddanych do ich dyspozycji „znanych” i wprowadzenie interesujących w mniemaniu twórcy „nowych”, pozwalających na kolejne poznawanie już poznanego.

\subsection{Czytelnik poznaje czytelnika}

Czytelnictwo fanfikcyjne wykracza poza schemat tradycyjnego odbioru literackiego, także jeśli chodzi o relacje między poszczególnymi czytelnikami dzieł oryginalnych i tekstów fanfikcyjnych. Relacje te nie polegają już (jak w tradycyjnym odbiorze literatury) na bliżej nieokreślonej przynależności do pewnej zbiorowości czytelniczej, identyfikowalnej w szerszym kontekście jedynie przez kolejne osoby, które zakupią dany bestseller, napiszą lub skomentują recenzję książki bądź polecą ją innym. Czytelnik fanfikcyjny zazwyczaj zdaje sobie sprawę z podobieństw i różnic w odbiorze literackim dzieła (i powstałych na jego bazie fikcji fanowskich), łączących i dzielących czytelników tych samych tekstów. 
Warto zaznaczyć, że czytelnik fanfikcyjny skłania się z ciekawością ku innym podejściom do wybranego dzieła literackiego, genezie jego poznawania i opiniowaniu. Trudno zawyrokować jednoznacznie, czy takie podejście do innych czytelników przyczynia się do powstania pewnej wspólnoty fanfikcyjnej (w dużej mierze fanowskiej). Pewne jest jednak, że generowanie w ramach tego typu piśmiennictwa coraz to bardziej różnorodnych rozwiązań fabularnych dla danego dzieła (czyli jego modyfikacji i rozbudowań) można odczytywać jako ważne źródło świadomości odbiorców co do innych czytelników. W ten sposób podkreślona zostaje indywidualność literackiego odbioru, która znajduje swoje odbicie w preferencjach dotyczących czytelnictwa konkretnych typów fikcji fanowskich.

\section{5. „Stara szkoła” w nowych szatach, czyli funkcja rozrywkowa}

Rozrywka jest jednym z podstawowych wyznaczników sięgania po literaturę, zwłaszcza w kulturze masowej. W takim kręgu rozumienia funkcji rozrywkowej należy umieścić również fan fiction, choć tego typu piśmiennictwo powstaje również, opierając się na dziełach nieuznawanych za wytwory kultury masowej. Mimo to do głównych przyczyn czytelnictwa fikcji fanowskich zaliczyć należy niewątpliwie właśnie chęć rozrywki i relaksu podczas lektury. W kontekście instrumentalizowania literatury poprzez fanfikcję warto pamiętać, że jest ona definiowana i rozumiana nie tylko jako faktyczna rozrywka, czytanie dla przyjemności, zazwyczaj mające równoważyć wkład wniesiony przez czytelnika w trakcie czytania i korzyści z niego czerpane (jak relaks czy oderwanie się od rzeczywistości), ale również jako przekształcanie tego wkładu.

Przekształcenia wkładu własnego w odbiór fikcji fanowskiej nie opiera się (tak jak w przypadku sięgania po zwyczajną oryginalną literaturę) na doborze dzieła, ale przede wszystkim na czytaniu kolejnych tekstów wpisanych (w większym lub mniejszym stopniu) w dobrze znany świat przedstawiony. Odróżnić trzeba to jednak od takich sytuacji, jak czytanie kolejnej części cyklu czy sagi. Fan fiction bowiem cechuje się większą różnorodnością, jeśli chodzi o styl pisania (w końcu tworzą je inne osoby niż autor dzieła oryginalnego), formę (często tworzone są bardzo krótkie utwory, tj. drabble lub w ramach zupełnie innego rodzaju literackiego niż dzieło oryginalne) i sytuacyjność bohaterów dzieła (umieszczanych często w fikcjach fanowskich w konfiguracjach, które nie miałyby szans zaistnieć w dziele oryginalnym, ponieważ narusza to pomysł na fabułę autora tegoż dzieła).

Zmianą w odbiorze jest przez to zwłaszcza inspiracja i zasadzanie się na znanym już literacko świecie, co jest wymogiem głównym, przy jednoczesnym poszukiwaniu kreatywnych (a przynajmniej odmiennych) rozwiązań literackich w piśmiennictwie.

\subsection{Edukacja na własne życzenie}

Funkcja edukacyjna $\mathrm{w}$ przypadku rozpatrywania literatury z perspektywy piśmiennictwa i czytelnictwa fanfikcyjnego pozbawia praktycznie całkowicie autora dzieła oryginalnego roli edukatora, zamiast niego umieszczając w tej roli samych odbiorców indywidualnych lu- 
b/i całe grupy osób skupione w danym środowisku fanfikcyjnym. Na podstawie literatury, która stała się obiektem miłośnictwa, dochodzi do edukacji czytelników, często nieświadomej i (co ważne) niekoniecznie celowej. Edukacja ta stanowi zazwyczaj (ale nie zawsze) produkt uboczny, coś, co dzieje się praktycznie przy okazji czerpania innych korzyści z fanfikcji.

Mimo to zasługuje ona na uwagę ze względu na szeroki wachlarz kształtowanych wśród odbiorców literackich umiejętności. Należą do nich:

- nauka języków obcych i tłumaczenia tekstów (do czego skłania odbiorców popularność wybranych fanfikcji obcojęzycznych);

- umiejętność recenzowania tekstów (umieszczenie fan fiction w sieci jest równoznaczne z oczekiwaniem na komentarz od jego czytelników);

- korekta tekstów (w ramach społeczności fanfikcyjnych rolę tę pełnią tzw. bety, beta-readerzy) $)^{29}$;

- nabywanie umiejętności piśmienniczych (w przypadku autorów fanfikcji);

- kształtowanie gustów literackich (w ramach wzajemnego wpływu poszczególnych członków społeczności fanfikcyjnych, różniących się wiekiem, profesją i doświadczeniem czytelniczym);

- rozwój wyobraźni (poprzez poznawanie bogactwa możliwych alternatyw dla opowieści oryginalnej);

- skrupulatność i przywiązanie do szczegółów w poznawaniu literackich fabul (co jest wynikiem brania udziału we wnikliwych analizach i dyskusjach na temat potencjalnych niedociągnięć i blędów w fabule dzieła oryginalnego).

Łączenie przyjemnego z pożytecznym w przypadku czytelnictwa i piśmiennictwa fan fiction pozwala na umiejscowienie tego typu aktywności w ramach działań edukacyjnorozrywkowych (edutainment), czyli nieformalnej edukacji polegającej na uczeniu się przy zabawie/przez zabawę $e^{30}$.

\section{Zamiast zakończenia}

Literatura, ujmowana przez pryzmat pełnionych funkcji, budzi wątpliwości. Z jednej strony trzeba podkreślić jej estetyczny wymiar, plasujący ją w obrębie sztuki dla sztuki, z drugiej nie sposób rozpatrywać literatury inaczej niż jako wielofunkcyjnej - jej potencjalne zastosowania (chociażby edukacyjne i rozrywkowe) niejednokrotnie w przypadku obcowania z tekstem literackim są tak oczywiste, że nie trzeba ich się specjalnie doszukiwać. Sytuacja się komplikuje, gdy do literackiej gry o funkcjonalność wkracza aktywny, wymagający i zaangażowany odbiorca, żyjący w czasach metakultury.

Tytułowe (z)użycie literatury to istnienie tekstu po tekście. Nie zawsze jego odbiorca może jednoznacznie stwierdzić, gdzie dany tekst miał swój początek. Czy należy za niego przyjąć pierwotną wersję tekstu, która została upubliczniona, czyli tekst oryginalny? Czy za początek może być uznana powstała na jego podstawie fanfikcja, z którą odbiorca ze-

${ }^{29}$ A. I. Karpovich, The Audience as Editor: The Role of Beta Readers in Online Fan Fiction Communities, [w:] Fan Fiction and Fan Communities in the Age of the Internet, red. K. Busse, K. Hellekson, Jefferson-London 2006, s. 171-188; S. Pugh, op. cit.

${ }_{30}$ M. Piechota, Działania edurozrywkowe w telewizji, [w:] Teorie komunikacji i mediów, red. M. Graszewicz, J. Jastrzębski, Wrocław 2010, s. 307-319. 
tknął się najpierw, a dopiero później sięgnął po autorskie dzieło oryginalne (jeśli w ogóle sięgnął!)? Co wyznacza istnienie tekstu: jego powstanie czy kontakt z odbiorcą? (Z)użycie literatury to istnienie tekstu pozbawionego autora, który po jego napisaniu i opublikowaniu utracił moc decyzyjną w stosunku do fabuły dzieła - a ta nadal się dzieje. Jest to równocześnie nadanie miana autorstwa piśmienniczym twórcom fan fiction, którzy tekst oryginalny modyfikują i rozbudowują, ulepszają i bezczeszczą, zmieniając wszystko to, co tylko zmienić podpowie im ich własna wyobraźnia. (Z)użycie literatury to przekraczanie granic przez odbiorców literackich. Granic poświęcanego na odbiór literatury wolnego czasu. Granic poznawania szczegółów wybranej literackiej fikcji. Granic znudzenia znajomością zakończenia dzieła oryginalnego. Granic przypisywanego dziełu literackiemu przez poszczególnych odbiorców znaczenia. Według Maryli Hopfinger:

Literatura drukowana - napisana, zredagowana, opracowana typograficznie w książce - była przez kilka stuleci stosownym i oczywistym sposobem wprowadzania do społecznego obiegu tekstów kultury, zróżnicowanych w treści i funkcjach, ale na ujednoliconych nośnikach. I właśnie to było w pełni funkcjonalne wobec przeświadczeń znakomitej większości ludzi kultury pisma i druku. „Tradycyjny druk” wyrastał z pewnej opartej na racjonalnych założeniach wizji świata, świata dającego się rozpoznać, opisać i przekazać wespół z wszystkimi dylematami, wątpliwościami, pytaniami bez odpowiedzi, w tekście wydrukowanym jednolitą czcionką, równymi wersami, zapełniającymi znormalizowane strony książỉ ${ }^{31}$.

Obecnie „drukowana” wizja świata jest co najwyżej preludium do jej re-kontekstualizacji.

Formułowanie końcowych wniosków w rozważaniach o fikcji fanowskiej wydaje się zdecydowanie przedwczesne. Trudno bowiem mówić o wyczerpaniu tematu instrumentalnych zastosowań literatury, kiedy jest ona nieustannie eksplorowana. Dalsze wykorzystania tekstów literackich, ich modyfikacje i zwielokrotnianie, będące wynikiem odbiorczych aktywności, może niechybnie doprowadzić do zwiększenia jej funkcjonalności, a nawet (i ta opcja nie musi być wcale odległą przyszłością czy nierealną alternatywą) krystalizowaniem się nowych i/lub wygórowanych oczekiwań względem autorów dzieł literackich. Być może, zamiast/obok pierwotnego tworzenia literatury czy też potencjalnej przychylności pisarzy względem tworzonych wokół literatury fanfikcji, pojawi się odbiorcze oczekiwanie wspóltworzenia dzieł oryginalnych przez autorów i czytelników czy też tworzenia fan fiction opartych na własnych dziełach autorskich przez pisarzy. I chociaż takie pojmowanie świata literackiego przekracza wszelkie schematy jego funkcjonowania, nie jest to wizja nieziszczalna. Tym sposobem jedna opowieść staje się wieloma historiami, inne historie skazując często na brak odbiorców, gdzie kwestią nierozstrzygniętą pozostaje to, czy dana historia nie zasługuje na uwagę czytelników.

Koniec końców zawsze chodzi o to, by dotrzeć do czytelnika. A rozpatrując sensowność istnienia literatury z perspektywy obecności czytelnika - to jemu należy się ostatnie słowo (jeśli kiedykolwiek zechce je wypowiedzieć).

${ }^{31}$ M. Hopfinger, op. cit., s. 130. 